\title{
Peutz-Jeghers families unlinked to STK11/LKB1 gene mutations are highly predisposed to primitive biliary adenocarcinoma
}

\author{
Sylviane Olschwang, Cécile Boisson, Gilles Thomas
}

\begin{abstract}
Introduction-Germline mutations of the STK11/LKB1 tumour suppressor gene (19p13.3) are responsible for PeutzJeghers syndrome (PJS), a rare genetic disorder, which is dominantly inherited. In addition to the typical hamartomatous gastrointestinal polyps and perioral pigmented lesions, PJS is also associated with the development of tumours in various sites. No specific follow up has yet been evaluated for gene carriers. Furthermore, genetic heterogeneity has been reported, which makes genetic counselling difficult. Methods-We report here the analysis of the STK11/LKB1 locus in a series of 34 PJS families, combining the search for mutations and rearrangements in the coding sequence, allele specific expression tests, and linkage studies.
\end{abstract}

Results-Germline deleterious mutation of the STK11/LKB1 gene were identified in $70 \%$ of cases. The hypothesis of a second PJS locus was reinforced and PJS families could be divided into two groups on the basis of the presence or absence of an identified STK11/LKB1 alteration. Analysis of clinical data indicates that the cancer associated risk is markedly different in the two groups. PJS patients with no identified $S T K 11 / L K B 1$ mutation are at major risk for proximal biliary adenocarcinoma, an infrequent tumour in the general population.

Conclusion-Up to $30 \%$ of PJS patients are caused by mutation in an unidentified gene that confers high susceptibility to cancer development.

(F Med Genet 2001;38:356-360)

Paris, France

S Olschwang

G Thomas

CEPH, Paris, France

C Boisson

G Thomas

CHU Saint-Antoine, Service de Chirurgie Digestive, Paris, France

S Olschwang

G Thomas

Correspondence to: Dr Olschwang,

olschwang@cephb.fr

Revised version received 14 March 2001

Accepted for publication

15 March 2001 risk for tumours at several sites (colon, pancreas, breast, ovary, testis, and cervix).

The PJS gene was mapped to chromosome 19 p13.3 by linkage analysis. Recently, germline mutations in the $S T K 11 / L K B 1$ gene have been reported as a molecular cause of PJS. ${ }^{12}$ The gene is divided into nine exons that encode a 433-aa protein, containing a serine/threonine kinase domain. The protein has been proposed to act as a tumour suppressor. ${ }^{3}{ }^{4}$ Although most of the tumours from PJS patients, even at an early stage, exhibit loss of the wild type allele, very few somatic mutations have been found in sporadic tumours. ${ }^{5-12}$ This observation suggests a frequent hamartoma-carcinoma sequence in PJS that is rarely featured in sporadic tumorigenesis.

While PJS is usually an early onset disease with characteristic clinical features, the high mutation rate, the lack of genotype-phenotype correlation, and the existence of a possible second locus makes individual predictive genetic testing difficult. ${ }^{13}{ }^{14}$ However, identification of a germline mutation in an index case allows the initiation of specific screening programmes for genetically affected kindreds.

We report here the results of a detailed phenotypic analysis and a systematic characterisation of the $S T K 11 / L K B 1$ locus in a series of 34 unrelated PJS families referred from different regions of France.

\section{Patients and methods}

PATIENTS

A total of 34 unrelated patients exhibiting extensive intestinal hamartomatous polyposis was referred to the laboratory for genetic analysis for PJS. The histological aspects of PJS polyps were unambiguous in all cases.

Clinical data were collected through patient interviews and hospital notes (table 1). No family data were available in two cases and 20 cases occurred without a previous family history, five of them having affected offspring.

Blood samples and informed consent were obtained from the patients and their relatives. DNA was extracted from $10 \mathrm{ml}$ of peripheral blood using the Nucleon ${ }^{\mathrm{TM}}$ BACC I kit (Amersham France, Les Ulis) according to the manufacturer's recommendations. Lymphoblastoid cell lines could be established for some samples. RNA was extracted from $10^{7} \mathrm{lym}-$ phoblastoid cells using the RNA $\mathrm{B}^{\mathrm{TM}}$ isolation kit (Quantum).

DNA samples from 24 unrelated subjects from the CEPH family panel were added as controls.
SEARCH FOR GERMLINE ALTERATIONS

The search for STK11/LKB1 mutations was performed on genomic DNA after PCR amplification of all nine exons and adjacent intronic sequences (for primers see table 2), purification on BioMag $^{\circledR}$ carboxyl-terminated 
Table 1 Clinical and family data of Pf patients

\begin{tabular}{|c|c|c|c|c|c|c|c|c|c|c|c|c|c|}
\hline \multirow{2}{*}{$\begin{array}{l}\text { Ped } \\
\text { No }\end{array}$} & \multirow{2}{*}{$\begin{array}{l}\text { Age at } \\
\text { diagnosis }\end{array}$} & \multirow{2}{*}{$\begin{array}{l}\text { No of } \\
\text { affected }\end{array}$} & \multirow{2}{*}{$\begin{array}{l}\text { Perioral } \\
\text { pigment }\end{array}$} & \multicolumn{4}{|c|}{ Hamartomatous lesions } & \multicolumn{6}{|c|}{ Carcinomas } \\
\hline & & & & Stomach & Duodenum & Colon & Ovary & Cervix & Breast & Kidney & Liver & Pancreas & Duodenum \\
\hline 9 & Child & $\geqslant 3$ & + & + & + & - & + & & & & $\begin{array}{l}\text { Father/gt } \\
\text { uncle }\end{array}$ & & $\begin{array}{l}\text { Aunt/gd } \\
\text { father }\end{array}$ \\
\hline 69 & Child & 3 & + & + & + & + & & & & & & & \\
\hline 118 & Infant & $\geqslant 2$ & + & - & + & - & & & & & & & \\
\hline 128 & Child & $\geqslant 1$ & - & - & + & $\begin{array}{l}+/ \\
\text { adenomas }\end{array}$ & + & & & & & & \\
\hline 199 & Child & $\geqslant 3$ & + & - & + & - & + & Mother & & & & & \\
\hline 229 & Infant & $\geqslant 3$ & + & - & + & - & & & & & & & \\
\hline 232 & Child & 1 & + & - & - & $\begin{array}{l}+/ \\
\text { adenomas }\end{array}$ & & & & & & & \\
\hline 277 & Adult & $\geqslant 4$ & + & - & + & - & Aunt & & $\begin{array}{l}\text { Gd } \\
\text { father }\end{array}$ & & & & \\
\hline 418 & Child & $\geqslant 3$ & + & - & + & + & & & & & & & \\
\hline 419 & Child & 1 & + & + & + & + & & & & & & & \\
\hline 442 & Child & 1 & + & + & + & + & & & & & & & \\
\hline 494 & Child & 2 & + & + & + & $\begin{array}{l}+/ \\
\text { adenomas }\end{array}$ & & & + & & Father & & \\
\hline 571 & Child & $\geqslant 2$ & + & + & + & + & & & & & & & \\
\hline 622 & Child & 1 & + & + & + & - & & & & & & & \\
\hline 626 & Child & 1 & + & + & + & - & & & & & & & \\
\hline 687 & Child & 1 & + & + & + & + & & & & Mother & & & \\
\hline 749 & Child & 2 & + & - & + & + & & & & & & & \\
\hline 795 & Child & $\geqslant 3$ & + & - & + & - & & & & & Gd father & & Mother \\
\hline 842 & Child & $\geqslant 2$ & + & - & + & + & & & & & & & + \\
\hline 919 & Adult & 1 & + & - & + & + & & & & & & & \\
\hline 1002 & Child & 2 & + & - & + & - & & & & & & & \\
\hline 1216 & Adult & 2 & + & + & + & + & & & & & & & \\
\hline 1475 & Child & 1 & + & + & + & + & & & & & & & \\
\hline 2174 & Infant & 1 & - & - & + & - & & & & & & & \\
\hline 2191 & Child & 1 & + & + & - & + & & & & & & & \\
\hline 2234 & Child & $\geqslant 2$ & + & - & + & + & & & & & & & \\
\hline 2295 & Child & $\geqslant 4$ & + & + & + & + & Mother & & & Mother & & Aunt & \\
\hline 2472 & Adult & $\geqslant 1$ & - & - & + & + & & & & & & + & \\
\hline 2494 & Child & $\geqslant 4$ & + & - & + & - & & & $+/$ Sister & & & & Father \\
\hline 2653 & Adult & 1 & + & + & + & + & & & & & & & \\
\hline 2678 & Adult & 1 & + & - & + & + & + & & & & & & \\
\hline 2688 & Child & 1 & + & + & + & + & & & + & & & & \\
\hline 2708 & Adult & 1 & + & - & + & + & & & & & & & \\
\hline 2733 & Child & 1 & - & + & + & + & + & & & & & & \\
\hline
\end{tabular}

beads (Bio Advance), and sequencing using Prism $^{\circledR}$ ready reaction dye terminator cycle sequencing kits and an $\mathrm{ABI} 310$ automated sequencer (Applied Biosystems Inc, Les Ulis). When a DNA variation was found, all available relatives of the corresponding family were tested.

The pair of primers $3 \mathrm{~L}-8 \mathrm{R}$ was also used to amplify a large DNA fragment containing the genomic region from exon 3 to exon 8 , which was electrophoresed on $1 \%$ agarose gels.

ALLELE SPECIFIC EXPRESSION TEST

Reverse transcription was performed on $1 \mu \mathrm{g}$ of total RNA using a $\mathrm{T}_{16}$ primer; PCR reactions were done on cDNA using a pair of primers located in exon 8 and 3'UTR respectively: 5'- CTACACTCAGGACTTCACGG and 5'- CAGCAGGGGAGGCCAGGGAA. PCR products, of an expected size of $1050 \mathrm{bp}$, were sequenced.
MICROSATELLITE POLYMORPHISM GENOTYPING Three microsatellite loci localised close to the STK11/LKB1 gene, D19S814, D19S536, and D19S886 (GDB comprehensive map), were genotyped after PCR amplification in a final volume of $20 \mu \mathrm{l}$. Amplified products ( $1 \mu \mathrm{l}$ of each) were electrophoresed in $6 \%$ polyacrylamide sequencing gels $(7 \mathrm{~mol} / 1$ urea and 32\% (v/v) formamide, acrylamide:bisacrylamide 29:1), then briefly transferred by capillary blotting onto a Hybond $\mathrm{N}+$ nylon membrane (Amersham, France). Membranes were hybridised with a $3^{\prime}$ labelled (CA) $)_{12}$ oligonucleotide that enabled the simultaneous detection of all amplified alleles, using the ECL direct nucleic acid labelling and detection system (Amersham, France, Les Ulis). Genotyping data were scored by comparison with the two reference DNA samples, CEPH134702 and CEPH88415. In each family, the probability for the disease to be linked to the STK11/LKB1

Table 2 Amplimers used for genomic PCR amplification of the STK11/LKB1 coding region

\begin{tabular}{ll}
\hline Exons & Amplimers \\
\hline 1 & 5'-ACAATCGTTTCTGTTGGAAG \& 5'-CCAGCTCAGGGTGTTAAGAG \\
2 & 5'-CACTGTGAACTCACAGCTTCTC \& 5'-AGCCATTGCCACAATGGCTGACTTC \\
3 & 5'-CCTGAGCTGTGTGTCCTTAGCG \& 5'-ATATCAGGACAAGCAGTGTG \\
4,5 & 5'-GTGTGGCTCCCTGCTGGACCTAGCCTTTC \& 5'-TACATTTCCATAAAGTAAGCACCCCCTA \\
6 & 5'-CGTCAACCACCTTGACTGACCACG \& 5'-CCTGCTGGGGTCTCGGGGCCAATAG \\
7 & 5'-TTAGGAGCGTCCAGGTATCACCC \& 5'-ACCCCCACCACGCCCTGCTCTAGCG \\
8 & 5'-GAGGACATGGCTGAGCTTCTGTGGT \& 5'-AAGCTGTCCTTGTTGCAGACA \\
9 & 5'-CAGCATTTCAGGCTGGATACACCT \& 5'-ACGGTCACCATGACTGACTA \\
3'UTR & 5'-TGTGGGGACAACGCCTGGA \& 5'-CAGCAGGGGAGGCCAGGGAA \\
\hline
\end{tabular}


Table 3 Germline mutations of the STK11/LKB1 gene

\begin{tabular}{|c|c|c|c|c|c|}
\hline Ped No & Exon & $\begin{array}{l}\text { Nucleotide } \\
\text { change }\end{array}$ & $\begin{array}{l}\text { Amino acid } \\
\text { consequence }\end{array}$ & $\begin{array}{l}\text { Biallelic } \\
\text { expression }\end{array}$ & $\begin{array}{l}\text { Two point lod } \\
\text { score }\end{array}$ \\
\hline 9 & & & & $\mathrm{Y}$ & +0.30 \\
\hline 69 & 5 & $725 \mathrm{G}>\mathrm{A}$ & G242V & - & \\
\hline $118^{\star}$ & 1 & $200 \mathrm{~T}>\mathrm{G}$ & L67R & - & \\
\hline 128 & 5 & $666 \mathrm{del}$ & $222 \mathrm{FS}$ & - & \\
\hline 199 & & & & $\mathrm{Y}$ & -2.40 \\
\hline $229^{\star}$ & 7 & 908del9 & 303del3 & - & \\
\hline 232 & & & & $\mathrm{Y}$ & \\
\hline 277 & 1 & $180 \mathrm{C}>\mathrm{G}$ & Y60X & - & \\
\hline 418 & 1 & 169del & $57 \mathrm{FS}$ & - & \\
\hline 419 & 2 & $354 \mathrm{C}>\mathrm{A}$ & Y118X & - & \\
\hline 442 & 5 & IVS $5+1 \mathrm{~g}>\mathrm{a}$ & & & \\
\hline 494 & & & & $\mathrm{Y}$ & +1.02 \\
\hline 571 & & & & $\mathrm{Y}$ & +0.84 \\
\hline 622 & 3 & $407 \mathrm{~T}>\mathrm{G}$ & M136R & - & \\
\hline 626 & 6 & 789del4 & $263 \mathrm{FS}$ & - & \\
\hline 687 & 1 & $153 \mathrm{del} 3$ & $52 \mathrm{del}$ & - & \\
\hline 749 & 6 & 753del & $251 \mathrm{FS}$ & - & \\
\hline 795 & & & & $\mathrm{Y}$ & +1.50 \\
\hline 842 & & & & $\mathrm{Y}$ & -2.42 \\
\hline 919 & 5 & 636del5 & $212 \mathrm{FS}$ & - & \\
\hline 1002 & 8 & 957del2ins T & $319 \mathrm{FS}$ & - & \\
\hline 1216 & 2 & 350insTTTG & $117 \mathrm{FS}$ & - & \\
\hline 1475 & 5 & $724 \mathrm{G}>\mathrm{T}$ & G242W & - & \\
\hline 2191 & 1 & IVS $1+1 \mathrm{~g}>\mathrm{a}$ & & & \\
\hline 2234 & 5 & IVS4-2a>t & & & \\
\hline 2295 & 6 & 841del & $281 \mathrm{FS}$ & - & \\
\hline 2472 & 4 & IVS3-2a $>\mathrm{g}$ & & & \\
\hline 2494 & 3 & $396 \mathrm{C}>\mathrm{A}$ & C132X & - & \\
\hline 2653 & 6 & IVS5-1g>a & & & \\
\hline 2708 & 6 & 744 del & $248 \mathrm{FS}$ & - & \\
\hline 2733 & 4 & $545 \mathrm{~T}>\mathrm{C}$ & L182P & - & \\
\hline
\end{tabular}

${ }^{\star}$ Previously reported by Hemminki et al. ${ }^{1}$

locus was calculated using the MLINK option (two point lod score) of the LINKAGE package.

Panel 11 of the ABI Prism ${ }^{\circledR}$ linkage mapping set LD20 (Applied Biosystem Inc, Les Ulis) was used to verify Mendelian segregation in case of de novo occurrence of the disease.

PHENOTYPIC ANALYSIS

Families were subdivided into two groups, according to the presence or absence of mutation at the $S T K 11 / L K B 1$ locus. Subjects were scored as affected when they were carrying a mutation (first group) and when they were clinically affected or obligate carriers (second group). The presence or absence of carcinoma was independently recorded. Association analyses were done with a chi-square test (StatView for MacIntosh).

\section{Results}

IDENTIFICATION OF STK11/LKB1 VARIANTS

Sequencing of the nine exons and the adjacent intronic regions led to the identification of 35 different variants in the 34 PJS patients and 11 in the 24 control cases. The 35 cases consisted of 17 mutations predicted to alter the open reading frame (three nonsense mutations, nine frameshift mutations, and five mutations in consensus splicing sites) and seven mutations of a priori unknown biological consequence (two in frame deletions and five missense mutations) (table 3 ). The remaining 11 variants were identical to those observed in the control population; they were all located in the 3'UTR region and the intronic sequences and were therefore considered as unrelated to the disease phenotype and called SNPs (table 4).

Amplification of the genomic fragment from exons 3 to 8 did not show any abnormality. For
Table 4 Polymorphisms of the STK11/LKB1 gene

\begin{tabular}{lll}
\hline Exon & Nucleotide change & Allele frequencies \\
\hline 1 & IVS1+36g $>\mathrm{t}$ & $0.75 / 0.25$ \\
2 & IVS2+24g $>\mathrm{t}$ & $0.875 / 0.125$ \\
3 & IVS3+49ins7 & $0.89 / 0.11$ \\
4 & IVS3-51c $>\mathrm{t}$ & $0.27 / 0.73$ \\
7 & IVS6-8c $>\mathrm{t}$ & $0.99 / 0.01$ \\
7 & IVS7+7g $>\mathrm{c}$ & $0.78 / 0.22$ \\
9 & 3'UTR+129c $>\mathrm{t}$ & $0.70 / 0.30$ \\
9 & 3'UTR+259g $>\mathrm{t}$ & $0.70 / 0.30$ \\
9 & 3'UTR+506g $>\mathrm{a}$ & $0.95 / 0.05$ \\
9 & 3'UTR+633c $>\mathrm{t}$ & $0.95 / 0.05$ \\
9 & 3'UTR+677t $>\mathrm{a}$ & $0.95 / 0.05$
\end{tabular}

22 of the 24 unique variants, it was possible to study multiple members of the corresponding family, and the DNA variants were not present in unaffected persons. In the 10 families containing at least two affected persons, all DNA variants were shown to cosegregate with the disease. In 10 out of 15 mutations found in patients without a previous family history of PJS, absence of the DNA variation in both parents of the proband, as well as Mendelian segregation of 11 polymorphisms, could be ascertained, thus showing the de novo occurrence of these mutations.

ALLELE SPECIFIC EXPRESSION ASSAY

DNA from 17 affected patients from the 10 families in which no mutation had been detected was tested for the 3'UTR polymorphisms. In seven families one or more affected patient was found to be heterozygous for at least one polymorphism. One heterozygous patient per family was selected for an allele specific expression assay. Double strand sequencing of RT-PCR products did not show unbalanced expression of the two STK11/ LKB1 alleles (table 3).

LINKAGE ANALYSES

Six of the 10 patients for whom no mutation could be detected were familial cases and were subsequently selected for linkage studies. DNA from both parents of a sporadic case was available and this family was added to the six others. A total of 37 DNA samples were genotyped for the three microsatellite polymorphisms D19S814, D19S536, and D19S886 and for the 11 intragenic SNPs. Positive lod scores were obtained in four families $(9,494$, 571, and 795). Families 199 and 842 were clearly unlinked to the STK11/LKB1 locus, with two point lod scores of -2.40 and -2.32 respectively (table 3 ). Mendelian inheritance was maintained in both familial and sporadic cases.

\section{PHENOTYPE-GENOTYPE ASSOCIATION}

In the 24 families with STK11/LKB1 mutation (group 1), there were 43 gene carriers, all clinically affected with symptomatic hamartomatous gastrointestinal polyps. In addition to hamartomatous polyposis, carcinomas at a young age ( $<50$ years) were detected in $19 \%$ of the gene carriers, with several locations (three breast, one small intestine, two renal, and two pancreatic carcinomas). In contrast, the 10 families without mutation (group 2) contained four obligate carriers (from four different fami- 
lies) exhibiting perioral pigmentation as the only manifestation of PJS and 16 symptomatic subjects, including 11 who had developed a carcinoma (two breast, four small intestine, four hepatic hilum, and one cervix) (table 1). Chi-square analysis of the data indicated significant differences in gastrointestinal expressivity ( $\mathrm{p}=0.01$ with correction) and in cancer associated risk $(p=0.0002)$ between the two groups, the risk being very high for proximal bile duct adenocarcinoma in group 2 when compared with group 1 and the general population (life time risk $=0.1-0.2 \%, \mathrm{p}<0.0001$ ).

\section{Discussion}

Genomic DNA sequencing of the STK11/ $L K B 1$ gene allowed the identification of 11 SNPs and 24 germline variants in a series of 34 well documented PJS patients. Seven of the latter were not predicted to lead to the synthesis of a truncated protein. The $200 \mathrm{~T}>\mathrm{C}$ mutation (family 118) changed the normal $\mathrm{Leu}^{67}$ into $\mathrm{Pro}^{67}$, and thus disrupted the highly conserved kinase core domain; in addition, this variation and 908del9 (family 229) were each present in three affected relatives. The five other variations (table 3 ) were de novo events that were detected in patients without a previous family history of PJS and cosegregated with the disease in offspring (family 69). Thus, all 24 variants were considered to be mutations responsible for PJS.

Additional genotyping of 11 biallelic and three microsatellite polymorphisms, located within or close to the $S T K 11 / L K B 1$ gene, confirmed the presence of a second PJS locus in at least two out of six familial cases. Mendelian segregation was validated in all informative cases, excluding the presence of null alleles. Moreover, PCR amplification of genomic DNA from exons 3 to 8 did not show abnormal fragments that might indicate internal gene deletion, but this approach precludes the detection of large rearrangements involving the 5' and/or 3' part of the gene. No allelic imbalance was found in RNA samples from seven unrelated patients of the 10 families without identified mutation, including one of the two unlinked cases. Taken together, these observations suggest that both STK11/LKB1 alleles were normally expressed, supporting the fact that they were not altered in the corresponding families. These data reinforce our previous linkage analyses and $\mathrm{LOH}$ studies using the D19S886 polymorphism, which indicated possible genetic heterogeneity in PJS. ${ }^{13}$

These combined analyses led to the identification of a STK11/LKB1 germline alteration in $70 \%$ of PJ patients, 15 of them being de novo mutations. Of the 10 cases without STK11/LKB1 alteration, five were sporadic, a proportion consistent with that observed in the case of mutation. Conversely, expressivity of the genetic defect appeared more severe; although four obligate carriers exhibited perioral pigment spots as the unique manifestation of the disease, 11 out of 16 symptomatic subjects developed a carcinoma, including four primitive biliary adenocarcinoma, which are rare tumours in the general population. Because all four carcinomas occurred in families compatible with $19 \mathrm{p}$ linkage, they might be associated with mutations in the STK11/ $L K B 1$ gene that escaped detection. However, affected patients in these families appear to have normally expressed STK11/LKB1 alleles. Although a recent compilation of reported carcinomas developing in a context of PJS did not show such a high frequency of biliary tract tumours, ${ }^{15}$ close study corroborates our observation. Familial Cowden disease (CD), familial Bannayan-Riley-Ruvalcaba syndrome (BRRS), and CD/BRRS overlap families have been screened for PTEN mutation. The significantly reduced mutation frequency in BRRS specific families, as had been already noted in cases of sporadic BRRS, suggested to the authors that this syndrome could be related to a specific genetic defect or another locus. ${ }^{16}$

In conclusion, the high frequency of cancers and the variations in the tumour spectrum of STK11/LKB1 negative PJS families, together with the presence of genetic heterogeneity, illustrate a severe variant of the disease caused by mutations in the putative second gene.

We are grateful to the following clinicians who provided samples and clinical information: Drs Bachy, Berthélémy, Cézard, Chapoy, Colombel, Dabadie, Dupas, Eugène, Gallot, Grandjouan, Guimbaud, Hammel, Jonveaux, Longy, Malafosse, Martin-Coignard, Mathieu, Maurage, Munck, Parc, Pariente, Plessis, Pocard, and Tiret. This work was supported by grants from Ligue Nationale Contre le Cancer and Association pour la Recherche sur le Cancer.

1 Hemminki A, Markie D, Tomlinson I, Avizienyte E, Roth S, Loukola A, Bignell G, Warren W, Aminoff M, Hoglund P, Jarvinen $\mathrm{H}$, Kristo P, Pelin K, Ridanpaa M, Salovaara R, Toro T, Bodmer W, Olschwang S, Olsen AS, Stratton MR, de la Chapelle A, Aaltonen LA. A serine/threonine kinase de la Chapelle A, Aaltonen LA. A serine/threonine kinase 1998;391:184-7.

2 Jenne DE, Reimann H, Nezu J, Friedel W, Loff S, Jeschke R, Muller O, Back W, Zimmer M. Peutz-Jeghers syndrome is caused by mutations in a novel serine threonine kinase. Nat Genet 1998;18:38-43.

3 Gruber SB, Entius MM, Petersen GM, Laken SJ, Longo PA, Boyer R, Levin AM, Mujumdar UJ, Trent JM, Kinzler $\mathrm{KW}$, Vogelstein B, Hamilton SR, Polymeropoulos $\mathrm{MH}$, Offerhaus GJ, Giardiello FM. Pathogenesis of adenocarcinoma in Peutz-Jeghers syndrome. Cancer Res 1998;58: 5267-70

4 Wang ZJ, Churchman M, Avizienyte E, McKeown C, Davies S, Evans DG, Ferguson A, Ellis I, Xu WH, Yan ZY, Aaltonen LA, Tomlinson IP. Germline mutations of the LKB1 (STK11/LKB1) gene in Peutz-Jeghers patients. F Med (STK11/LKB1) gene

5 Wang ZJ, Taylor F, Churchman M, Norbury G, Tomlinson I. Genetic pathways of colorectal carcinogenesis rarely involve the $P T E N$ and $L K B 1$ genes outside the inherited hamartoma syndromes. Am f Pathol 1998;153:363-6.

6 Resta N, Simone C, Mareni C, Montera M, Gentile M, Susca F, Gristina R, Pozzi, Bertario L, Bufo P, Carlomagno N, Ingrosso M, Rossini FP, Tenconi R, Guanti. STK11/ LKB1 mutations in Peutz-Jeghers syndrome and sporadic
colon cancer. Cancer Res 1998;58:4799-801.

Guldberg P, Thor Straten P, Ahrenkiel V, Seremet T, Kirkin $\mathrm{AF}$, Zeuthen J. Somatic mutation of the Peutz-Jeghers syndrome gene, LKB1/STK11, in malignant melanoma. Oncogene 1999;18:1777-80

8 Nishioka Y, Kobayashi K, Sagae S, Sugimura M, Ishioka S, Nagata M, Terasawa K, Tokino T, Kudo R. Mutational analysis of $S T K 11 / L K B 1$ gene in ovarian carcinomas. $f p n \mathcal{F}$ Cancer Res 1999;90:629-32.

9 Su GH, Hruban RH, Bansal RK, Bova GS, Tang DJ, Shekher MC, Westerman AM, Entius MM, Goggins M, Yeo CJ, Kern SE. Germline and somatic mutations of the STK11/LKB1 Peutz-Jeghers gene in pancreatic and biliary cancers. Am F Pathol 1999;154:1835-40.

10 Wang ZJ, Churchman M, Campbell IG, Xu WH, Yan ZY, McCluggage WG, Foulkes WD, Tomlinson IP. Allele loss and mutation screen at the Peutz-Jeghers (LKB1) locus (19p13.3) in sporadic ovarian tumours. Br f Cancer 1999; 80:70-2. 
11 Bignell GR, Barfoot R, Seal S, Collins N, Warren W, Stratton MR. Low frequency of somatic mutations in the LKB1/Peutz-Jeghers syndrome gene in sporadic breast cancer. Cancer Res 1998;58:1384-6.

12 Avizienyte E, Roth S, Loukola A, Hemminki A, Lothe RA, Stenwig AE, Fossa SD, Salovaara R, Aaltonen LA. Somatic mutations in $L K B 1$ are rare in sporadic colorectal and testicular tumors. Cancer Res 1998;58:2087-90.

13 Olschwang S, Markie D, Seal S, Neale K, Phillips R, Cottrell $\mathrm{S}$, Ellis I, Hodgson S, Zauber P, Spigelman A, Iwama T, Loff S, McKeown C, Marchese C, Sampson J, Davies S, Talbot I, Wyke J, Thomas G, Bodmer W, Hemminki A, Avizienyte E, de la Chapelle A, Aaltonen L, Tomlinson I. Peutz-Jeghers disease: most, but not all, families are compatible with linkage to 19p13.3. F Med Genet 1998;35 $42-4$.
14 Mehenni H, Gehrig C, Nezu J, Oku A, Shimane M, Rossier C, Guex N, Blouin JL, Scott HS, Antonarakis SE. Loss of LKB1 kinase activity in Peutz-Jeghers syndrome, and evidence for allelic and locus heterogeneity. Am $\mathcal{F} \mathrm{Hum}$ Genet 1998;63:1641-50.

15 Hemminki A. The molecular basis and clinical aspects of Peutz-Jeghers syndrome. Cell Mol Life Sci 1999;55:735-50. 16 Marsh DJ, Kum JB, Lunetta KL, Bennett MJ, Gorlin RJ, Ahmed SF, Bodurtha J, Crowe C, Curtis MA, Dasouki M, Dunn T, Feit H, Geraghty MT, Graham JM Jr, Hodgson SV, Hunter A, Korf BR, Manchester D, Miesfeldt S, Murday VA, Nathanson KL, Parisi M, Pober B, Romano C, Tolmie J, Trembath R, Winter RM, Zackai EH, Zori RT, Weng LP, Dahia PLM, Eng C. PTEN mutation spectrum and genotype-phenotype correlations in Bannayan-RileyRuvalcaba syndrome suggest a single entity with Cowden syndrome. Hum Mol Genet 1999;8:1461-72.

\title{
1st Asia Pacific Forum on Quality Improvement in Health Care
}

Three day conference

\section{Wednesday 19 to Friday 21 September 2001 Sydney, Australia}

We are delighted to announce this forthcoming conference in Sydney. Authors are invited to submit papers (call for papers closes on Friday 6 April), and delegate enquiries are welcome. The themes of the Forum are:

- Improving patient safety

- Leadership for improvement

- Consumers driving change

- Building capacity for change: measurement, education and human resources

- The context: incentives and barriers for change

- Improving health systems

- The evidence and scientific basis for quality improvement.

Presented to you by the BMJ Publishing Group (London, UK) and Institute for Healthcare Improvement (Boston, USA), with the support of the the Commonwealth Department of Health and Aged Care (Australia), Safety and Quality Council (Australia), NSW Health (Australia), and Ministry of Health (New Zealand).

For more information contact: quality@bma.org.uk or fax +44(0)20 73836869

\section{Narrative Based Medicine, An Interdisciplinary Conference}

\author{
Research, Narrative, and Practice
}

A two day conference-Monday 3rd and Tuesday 4th September 2001

$$
\text { Homerton College, Cambridge, UK }
$$

\section{BMF Publishing Group}

For full details contact: BMA/BMJ Conference Unit, Tavistock Square, London, WC1H 9JP Tel: +44 (0)20 7383 6819; fax: +44 (0)20 7383 6663; email: clyders@bma.org.uk.

www.quality.bmjpg.com 